\title{
The Effects of Some Environmental Factors on Birth Weight and Estimation of Heritability and Repeatability for Birth Weight of Akkaraman Sheep in Konya Province
}

\author{
Ayhan Öztürk' ${ }^{1}$ Şükrü Doğan², Uğur Zülkadir ${ }^{*}$, Halil Kayar² \\ ${ }^{1}$ Department of Animal Science, Faculty of Agriculture, Selcuk University, 42070 Konya, Turkey \\ ${ }^{2}$ Bahri Dağdas International Agricultural Research Institute, 42070 Konya, Turkey
}

\begin{tabular}{l}
\hline A R T I C L E I N F O \\
\hline Research Article \\
Received 15 June 2018 \\
Accepted 03 November 2018 \\
\hline
\end{tabular}

Keywords:

Akkaraman

Sheep

Lamb

Birth weight

Environmental factors

*Corresponding Author:

E-mail: uzulkad@ @elcuk.edu.tr

\begin{abstract}
A B S T R A C T
In this research, the effects of dam age and type of birth and sex of lambs on birth weight of Akkaraman lambs was investigated at village conditions in Konya province. Additionally, the heritability and repeatability of birth weight was estimated. The Leastsquares means of birth weight was $4.07 \pm 0.04 \mathrm{~kg}$. The effects of dam age, year, birth type and sex on birth weight were found statistically significant. The heritability and repeatability of birth weight were found as $0.052 \pm 0.04$ and $0.130 \pm 0.04$, respectively.
\end{abstract}

DOI: https://doi.org/10.24925/turjaf.v6i12.1755-1757.2068

\section{Introduction}

The increase in sheep meat production depends on high fertility, birth weight, survival and development of lambs (Öztürk et al., 1996). The growth is influenced a variety factors such as genotype, sex, birth type and nutrition factors.

There is a linear relationship between the birth weight and live weight at weaning and in older ages. For this reason, birth weight is considered as an important criterion for later periods of live weight in the selection processes. At the same time, success in selection depends also on the knowledge of genetic parameters which dwelled on. The most important ones of these parameters are repeatability and heritability.

The Akkaraman sheep consist of approximately 45 percent of sheep population in Turkey is a native important genotype and dominant breed of middleAnatolia region.

The purpose of this research was to investigate the effects of some environmental factors on birth weight and to estimate heritability and repeatability for birth weight in Akkaraman lambs.

\section{Materials and Methods}

In this study, data were obtained from records from 2013 until 2016 were used. 1333 of records on birth weight in Akkaraman ewes maintained by breeders in Yarma village of Karatay district of Konya province were utilized.

In this research, Akkaraman ewes aged between 2 and 7 years were used. The sheep were grazed from April to November and the other months they were kept in their pens. They were fed an average of 400-500 $\mathrm{g}$ rolled barley, sugar beet pulp and 500-600 g wheat straw per sheep in their pens. Also, they had always water on their corrals. The feeding times were between 6-7 am and 5-6 pm.

The flocks were hand-mated in September and October. There was no supplementary feeding for ewes or rams before or during the mating. Sheep lambed from mid-February until mid-April. The number of lambs born and their sex, birth type, birth weight and ewe's age were recorded. Birth weights of lambs were measured by weighing 100 grams of sensitivity within 24 hours after birth. 
The data were analyzed by mixed models with a leastsquares and maximum likelihood general purpose program developed by Harvey (1987). It has been used to estimate the heritability from the resemblance of paternal half siblings. Comparisons among the subclass means were carried out using Duncan's multiple range test (Düzgüneş et al., 1983) using MSTAT-C Range Program.

Heritability $\left(\mathrm{h}^{2}\right)$ and repeatability $(\mathrm{r})$ were obtained applying the following formulas, respectively:

$$
\begin{aligned}
& \mathrm{h}^{2}=4 * \mathrm{~V}_{\mathrm{A}} / \mathrm{V}_{\mathrm{P}} \\
& \mathrm{r}_{\mathrm{g}}=\operatorname{Cov}\left(\mathrm{A}_{1}, \mathrm{~A}_{2}\right) / \operatorname{Sqrt}\left(\mathrm{V}_{\mathrm{A} 1} * \mathrm{~V}_{\mathrm{A} 2}\right) \\
& \mathrm{r}=\mathrm{V}_{\mathrm{A}}+\mathrm{V}_{\mathrm{pe}} / \mathrm{V}_{\mathrm{P}} \\
& \text { in the formulas; } \\
& \mathrm{V}_{\mathrm{A}}=\text { Additive genetic variance } \\
& \mathrm{V}_{\mathrm{P}}=\text { Phenotypic Variance } \\
& \mathrm{V}_{\mathrm{pe}}=\text { Permanent Environment } \\
& \mathrm{r}_{\mathrm{g}}=\text { Genetic Correlation. }
\end{aligned}
$$

The mathematical model used for the least-squares analysis of variance of birth weight was:

$$
\mathrm{Y}_{i j k l m}=\mu+\mathrm{a}_{i}+\mathrm{b}_{j}+\mathrm{c}_{k}+\mathrm{d}_{l}+\mathrm{e}_{i j k l m}
$$

Were $\mu$ is the overall mean,

$$
\begin{array}{ll}
\mathrm{a}_{i} & : \text { effect of dam ages, } i=1, \ldots 6(2-7 \text { ages }), \\
\mathrm{b}_{\mathrm{j}} & : \text { effect of year, } j=1,2,3(2013-2016), \\
\mathrm{c}_{k} & : \text { effect of birth type, } k=1,2(\text { single, twin), } \\
\mathrm{d}_{l} & : \text { effect of sex of lamb, } l=1,2 \text { (male, female), } \\
\mathrm{e}_{i j k l m} & \text { :random error. }
\end{array}
$$

\section{Results and Discussion}

The least-squares means with their standard errors and tests of significance for factors affecting birth weight of Akkaraman lambs are shown in Table 1.
The least-squares mean for birth weight was $4.07 \pm 0.04 \mathrm{~kg}$. This value was similar to $3.97 \mathrm{~kg}$ reported by Öztürk and Gürkan (2000) for Akkaraman sheep, and similar to $4.00 \mathrm{~kg}$ for the same breed reported by Y1lmaz (2006), but this value was heavier than Karakaş genotype (a variety of Akkaraman, $3.18 \mathrm{~kg}$ ) reported by Gökdal et al. (2004), and by Boztepe et al. (1994) (for Akkaraman lambs, $3.85 \mathrm{~kg}$ ). However, it was lighter than the $4.67 \mathrm{~kg}$ value reported for Akkaraman sheep (Öztürk, 1995), and Dağ et al. (2000) reported value for Akkaraman sheep as $4.278 \mathrm{~kg}, 4.915 \mathrm{~kg}$ value reported for Akkaraman sheep (Çolakoğlu and Özbeyaz 1999). The birth weight was significantly affected by dam age, year, birth type and sex of lambs $(\mathrm{P}<0.01)$. Similar findings were reported by Öztürk and Boztepe (1994) for Akkaraman, Öztürk et al. (1996) for Konya Merino, Sezgin et al. (2012) for Hemşin lambs and Dağ et al. (2000) for Akkaraman lambs. There are also some findings have reported different results (Öztürk 1995; Öztürk and Gürkan 2000).

Generally, it is expected to be an increase in birth weight with advancing age of the dam. It is known that male lambs for birth weight have heavier than female lambs, indicating that it changes based on sexing of lamb. Similarly, birth weight in lambs' changes according to the type of birth. So, single lambs for birth type are heavier than twin ones. Birth weight may vary depending on the

\begin{tabular}{|c|c|c|c|}
\hline \multirow{2}{*}{ Trait effect } & \multicolumn{3}{|c|}{ Birth Weight (kg) } \\
\hline & $\mathrm{n}$ & Mean & $\mathrm{SE}$ \\
\hline Overall mean & 1333 & 4.07 & 0.04 \\
\hline Dam age & $* *$ & & \\
\hline 2 & 245 & $3.93^{\mathrm{c}}$ & 0.04 \\
\hline 3 & 301 & $4.06^{\mathrm{abc}}$ & 0.04 \\
\hline 4 & 447 & $4.22^{\mathrm{a}}$ & 0.03 \\
\hline 5 & 252 & $4.14^{\mathrm{a}}$ & 0.04 \\
\hline 6 & 80 & $4.10^{a b}$ & 0.08 \\
\hline 7 & 8 & 3.97 bc & 0.23 \\
\hline Year & $* *$ & & \\
\hline (1) 2013-2014 & 433 & $3.68^{c}$ & 0.05 \\
\hline (2) 2014-2015 & 468 & $4.16^{b}$ & 0.05 \\
\hline (3) $2015-2016$ & 432 & $4.37^{\mathrm{a}}$ & 0.05 \\
\hline Birth Type & $* *$ & & \\
\hline Single & 919 & $4.42^{\mathrm{a}}$ & 0.05 \\
\hline Twin & 414 & $3.72^{b}$ & 0.05 \\
\hline Lamb gender & $* *$ & & \\
\hline Male & 670 & $4.16^{b}$ & 0.05 \\
\hline Female & 663 & $3.98^{\mathrm{a}}$ & 0.05 \\
\hline
\end{tabular}
year. Indeed, farm conditions in sheep breeding can vary from year to year. As healthcare and feeding conditions applied to the animals will be different, improving levels in the farm can vary from year to year.

In the present study, It has founded that the age of dam (ewe) had a significant effect on birth weight $(\mathrm{P}<0.01)$. The averages and standard errors of age groups and differences between groups were presented in Table 1. The findings of this study about birth weight is in agreement with the reports of Öztürk et al. (1996), Gökdal et al. (2004) and Dağ et al. (2000). There are not contrary results among the literature.

Table 1 Least-squares means (LSM) and standard errors (SE) for birth weight of Akkaraman sheep 
The "year" factor includes some factors such as climatic, management, nutrition and husbandry elements, and it significantly affected birth weight of lambs in the present study $(\mathrm{P}<0.01)$. Similar findings have been reported by Öztürk (1995), Öztürk et al. (1996) and Sezgin et al. (2012).

The average birth weight of 919 single and 414 twin lambs were 4.42 and $3.72 \mathrm{~kg}$, respectively. The $0.70 \mathrm{~kg}$ difference in favor of single lambs was very significant $(\mathrm{P}<0.01)$. This result was consistent with the literature in general (Gökdal et al., 2004; Şireli and Ertuğrul, 2005; Y1lmaz, 2006; Altıoglu, 2007).

The birth weight of 670 male and 663 female lambs were 4.16 and 3.98 , respectively. The difference between the averages is significant $(\mathrm{P}<0.01)$. This result was in agreement with the results reported by Gökdal et al. (2004) for Karakaş, Şireli and Ertuğrul (2005) for Akkaraman, Yılmaz (2006) for Akkaraman, Altığlu (2007) for Kangal Akkaraman lambs, and Dağ et al. (2000) for Akkaraman lambs.

The repeatability of birth weight was estimated as $0.130 \pm 0.036$. This finding was similar to repeatability of birth weight in Akkaraman breed with 0.11 (Öztürk, 1995). However, this repeatability of birth weight for Akkaraman lambs that of 0.13 was less than value of 0.23 obtained by Dağ et al. (2000) for Akkaraman, and 0.26 reported by Koyuncu et al. (2001) for Karacabey Merino sheep, 0.30 reported by Gamasaee et al. (2010) for Mehraban sheep. On the other hand; this study value was higher than Lohi sheep reported by Babar et al. (2003) as 0.108 .

The heritability of birth weight was found as $0.052 \pm 0.036$, in the present study. Düzgüneş et al. (1991) reported that heritability estimates of birth weight were between 0.05 and 0.63 . This value estimated in the study was higher than the findings of Öztürk and Boztepe (1994); (0.007), for Akkaraman breed. In contrast, this value was lower than heritability estimates of birth weight for Karacabey Merino (0.23) and Hemşin breeds (0.21), reported by Koyuncu et al. (2001) and Sezgin et al. (2012), respectively.

According to these results, in lamb meat production, it is indicated that birth weight as a selection criteria is not enough for an effective genetic progress only. The low heritability of birth weight shows that it is not to the genetic variation for this trait. At the same time it was founded that the repeatability of birth weight in Akkaraman of lambs was low. It is stated that it cannot be made a selection according to the first yield data for birth weight, so in the future, birth weight cannot be repeated in the same way.

\section{Acknowledgements}

This study was supported by the General Directorate of Agricultural Research and Policy in Turkey, through the project called "Improvement of Akkaraman sheep under breeder conditions in Konya Province" (42AKK2011-02). This is one of the many projects under the main project called "National Genetic Improvement Project for Small Ruminants at Breeders' Conditions".

\section{References}

Altıoğlu A. 2007. Adana ili Tufanbeyli ilçesi köylerinde koyun yetiştiriciliğinin karakterizasyonu, Basılmamış Yüksek Lisans Tezi, Çukurova Üniversitesi Fen Bilimleri Enstitüsü, Adana.

Babar ME, Ahmad Z and Hussain A. 2003. Heritability estimates of birth and weaning weight in Lohi sheep., Pak. J. Agr. Sci., 40: 3-4.

Boztepe S, Özbayat Hİ, Dağ B. 1994. Akkaraman koyunlarında bazı çevre faktörlerinin doğum ve sütten kesim ağırlığına etkileri. Selçuk Üniversitesi Ziraat Fakültesi Dergisi, 5 (7): 172-181.

Çolakoğlu N, Özbeyaz C. 1999. Akkaraman ve Malya koyunlarının bazı verim özelliklerinin karşılaştırılması. Turkish Journal of Veterinary and Animal Sicences, 23: 351-360.

Dağ B, Boztepe S, Özbayat Hİ. 2000. Akkaraman koyunlarında bazı çevre faktörlerinin kimi verim özelliklerine etkileri ve bu özelliklerin tekrarlanma derecesi. Hayvancılık Araştırma Dergisi, 10 (1): 11-16.

Düzgüneş O, Kesici T, Gürbüz F. 1983. İstatistik metotları I. Ankara Üniversitesi Ziraat Fakültesi Yayın No: 861, Ankara.

Düzgüneş O, Eliçin A, Akman N. 1991. Hayvan 1slahı. Ankara Üniversitesi Ziraat Fakültesi Yayınları, Yayın No: 1212, Ankara.

Gamasaee VA, Hafezian SH, Ahmadi A, Baneh H, Farhadi A, Alborz M. 2010. Estimation of genetic parameters for body weight at different ages in Mehraban sheep. African Journal of Biotechnology, 9 (32): 5218-5223.

Gökdal Ö, Ülker H, Karakuş F, Cengiz F, Temur C, Handil H. 2004. Growth, feedlot performance and carcass characteristics of Karakas and crossbred lambs $\left(\mathrm{F}_{1}\right)$ (Ile de France x Akkaraman $\left(\mathrm{G}_{1}\right)$ x Karakas) under rural farm conditions in Turkey. South African Journal of Animal Science, 34 (4): 223-232.

Harvey WR. 1987. User's guide for LSMLMW PC-1 version mixed model least-squares and maximum likelihood computer program. Ohio State University, Columbus, Mimeo.

Koyuncu M, Tuncel E, Uzun ŞK. 2001. Karacabey Merinosu koyunlarında doğum ağırlığı ve gebelik süresine bazı çevre faktörlerinin etkileri ve genetik parametreler. Atatürk Üniversitesi Ziraat fakültesi dergisi, 32 (2): 163-167.

Öztürk A, Boztepe S. 1994. Akkaraman ve İvesi koyunlarının doğum ağırlı̆̆ının kalıtım derecesi. Turkish Journal of Veterinary and Animal Sciences, 18: 205-208.

Öztürk A. 1995. Akkaramanlarda doğum ağırlığı ve gebelik süresinin tekrarlanma dereceleri. Selçuk Üniversitesi Ziraat Fakültesi Dergisi, 6 (8): 188-193.

Öztürk A, Aktaş AH, Gürkan M. 1996. Konya Merinosu koyunlarının doğum ağırlığının kalıtım derecesi. Turkish Journal of Veterinary and Animal Sciences, 20: 411-414.

Öztürk A, Gürkan M. 2000. The effect of body weight at service on gestation length and birth weight in Akkaraman and Awassi Ewes. Indian Veterinary Journal, 77:686-688.

Sezgin E, Kopuzlu S, Yüksel S, Esenbuğa N, Bilgin ÖC. 2012. Determination of growth traits and heritabilities of growth characteristics of Hemşin sheep reared in Artvin. Kafkas Üniversitesi Veteriner Fakültesi Dergisi, 18 (6): 899-905.

Şireli H, Ertuğrul M. 2005. Akkaraman, GD1x GD1 (Dorset Down $\mathrm{x}$ Akkaraman) ve Akkaraman $\mathrm{x} \mathrm{GD}_{1}$ genotipli kuzularda canlı ağırlık ve vücut ölçülerinin tekrarlanma dereceleri. Tarım Bilimleri Dergisi, 11 (1): 1-6.

Y1lmaz A. 2006. Saf Akkaraman 1rk1 ve melez kuzuların doğum ağırlıklarını etkileyen makro çevre faktörlerinin etki miktarlarının hesaplanması. (Basılmamış Yüksek Lisans Tezi), Ankara Üniversitesi Fen Bilimleri Enstitüsü, Ankara. 